\title{
EDITORIAL
}

\section{Risk factors for multi-resistant acquired tuberculosis}

An adequate analysis of factors associated to multiresistant tuberculosis (MRTB) in the State of Ceará (Brazil), published by Barroso et al. ${ }^{(1)}$ in this issue, is highly relevant and pertinent, due to the comments about a major and feared problem of difficult control, which has increased all over the world from the early 90 ' ${ }^{(2)}$. The authors emphasize that the rate of combined MRTB (primary and acquired) has been increasing in Ceará and Brazil throughout the 90' ${ }^{(3)}$. Moreover, as referred in the manuscript, Becerra et al. ${ }^{(4)}$ emphasize that recently Brazil started to be considered as one of priority places for evaluation of and intervention on MRTB, even with data collected in the National Survey of 1996, with primary $(0.9 \%)$ or combined (1.3\%) MRTB rates lower than those accepted by the World Health Organization (WHO) as a discrimen threshold $(2.2 \%)$ as an alert signal ${ }^{(5)}$. In this study, primary MRTB cases, family history of MRTB, intra-institutional variables associated to the transmission, such as hospitals and/or jail and the role of HIV infection and use of illegal drugs due to the low frequency in the population studied, were not included. Therefore, such results refer to the analysis of acquired MRTB-associated factors usually accepted as a consequence of human error ${ }^{(6)}$.

Positive aspects of the article that was the subject of the first author's Master's dissertation:

a) It is one of the few manuscripts on MRTB published in national journals with methodology worth praising. This study, rather than describing a case series that leads to few speculations, reports an appropriate, retrospective, matched populational-base case-control study, which raises important questioning;

b) It has valued the activities of a tuberculosis reference laboratory, demonstrating the high impact of such information, when analyzed together with sociodemographic, clinical and laboratory variables, usually not included in basic research or even clinical series studies;

c) Standardized definitions on the variables described in the data collection tools were included, allowing the comparison with other settings, both in our country as in others. Among these, we can mention the International definition of MRTB (the bacillus resistant to, at least riphampicine (RPP) + izonizide $\left.(\mathrm{INH})^{(5)}\right)$, of alcoholism ${ }^{(7)}$, of smoking ${ }^{(8)}$ and of irregular use of medication (failure to use medication for five or more consecutive days, or 10 or more alternate days, as long as it does not reach 30 days in one month); d) A single flaw refers to the evaluation of the presence of cavities in the control group (TB sensitive) performed after the first discharge or at the time of the interview, because this conduct might have led to a classification bias;

e) The data analysis used statistical inferences appropriate to this kind of study, originating a prediction model of $84.4 \%$, with $73.3 \%$ sensitivity and $91.3 \%$ specificity;

f) The results were correctly addressed in the discussion, regarding their limitations.

The factors significantly associated to TBMR occurrence after the multiple linear regression were: a) lack of sanitary infra-structure at home (water and sewage); b) alcoholism + smoking; c) number of previous treatments; d) irregular treatments, and e) lung cavities.

As emphasized in this study, most of the authors describe the number of previous treatments ${ }^{(9)}$, alcoholism $^{(9)}$, cavity in the thoracic radiogram ${ }^{(10)}$ and treatment irregularities ${ }^{(11)}$ as TBMR associated factors. However, smoking and lack of home sewage came up as variables not mentioned in the literature. The first one elicits the performance of studies on the immunepathogenesis field, and the second one confirms the socioeconomic influence in this context. It is important to emphasize that the risk of MRTB development was 7.01 among the cases of irregular treatment against a risk of 2.73 among the cases of treatment drop-outs. The mention of a previous treatment with irregular use of medication was more important than the treatment dropout, and its identification must be a priority in places where a routine of supervised treatment has not yet been adopted, as suggested by the $\mathrm{WHO}$ and, more recently, by the Brazilian Health Ministry.

Finally, it must be emphasized that the quality of the mentioned study resulted in a joint action between professionals acting in a service net (LACEN, State Health Department and Health Ministry) and in the University. Such activities must be prioritized in our environment, specially by the strictu sensu graduate courses, where Masters dissertations or Ph.D. Thesis should aim at answering questions relevant to the Brazilian Public Health and not be restricted to basic, pre-clinical or clinical research disconnected from our reality ${ }^{(12)}$.

Prof. Dr. AfrÂNIO LINEU KRITSKI Universidade Federal do Rio de Janeiro 


\section{REFERENCES}

1. Barroso EC, Motta RMS, Santos RO, Sousa ALO, Barroso JB, Rodrigues JLN. Fatores de risco para tuberculose multirresistente adquirida. J Pneumol 2003;29:89-97.

2. Horsburgh Jr CR. The global problem of multidrugresistant tuberculosis: the genie is out of the bottle. JAMA 2000;283:2575-6.

3. Barroso EC, Rodrigues JLN, Pinheiro VGF, Campelo CL. Prevalência da tuberculose multirresistente no Estado do Ceará, 1990-1999. J Pneumol 2001;27:310-14.

4. Becerra MC, Bayona J, Freeman J, Farmer PE, Kim JY. Redefining MDR-TB transmission 'hot spots'. Int J Tuberc Lung Dis 2000;4:387-94.

5. Pablos-Mendez A, Raviglione MC, Laszlo A, Binkin N, Rieder HL, Bustreo F, et al. Global surveillance for antituberculosis-drug resistance, 1994-1997. World Health Organization- International Union against Tuberculosis and Lung Disease Working Group on Anti-tuberculosis Drug Resistance Surveillance. N Engl J Med 1998;338:1641-9.
6. Mahmoud AMD, Michael D, Iseman MD. Pitfalls in the care of patients with tuberculosis: common errors and their association with the acquisition of drug resistance. JAMA 1993;270:65-8.

7. O'Connor PG, Schottenfeld RS. Patients with alcohol problems. N Engl J Med 1998;338:592-600.

8. Fahn HJ, Wang LS, Kao SH. Smoking-associated mitochondrial DNA mutations and lipid peroxidation in human lung tissues. Am J Respir Cell Mol Biol 1998; 19:901-9.

9. Torres L. Resistance of Mycobacterium tuberculosis in Zaragoza, Spain (1993-1997) and related factors. Med Clin (Barc) 2000;115:605-9.

10. Ben-Dov I, Mason GR. Drug-resistant tuberculosis in Southern California Hospital: Trends from 1969 to 1984. Am Rev Respir Dis 1987;135: 1307-10.

11. Snider Jr DE, Long MW, Cross FS, Farer LS. Six-months isoniazid-rifampin therapy for pulmonary tuberculosis. Am Rev Respir 1984;129: 573.

12. Relatório final do Seminário de Prospecção em Ensino, Pesquisa, Assistência e Extensão na área da Saúde da UFRJ. Rio de Janeiro, 6-7 de dezembro de 2002. Mimeografado 